\title{
Overview on the Applications and Effects of Peptides in the Therapeutic
}

\author{
Mozhdeh Haddadi ${ }^{1 *}$ and Soroush Sardari ${ }^{2}$ \\ ${ }^{1}$ Department of Biochemistry, Tarbiat Modares University, Iran \\ ${ }^{2}$ Department of Bioinformatics and Drug design, Institute Pasteur, Tehran, Iran
}

Submission: April 02, 2017; Published: May 02, 2017

*Corresponding author: Soroush Sardari, Department of Bioinformatics and Drug design, Institute Pasteur, Tehran, Iran, Tel: 982164112435 ,

Email: ssardari@hotmail.com

Abstract

Peptides and bioactive proteins are detected as new therapeutic molecules with changing biological attributes for potential medical claims. With attention to their practical properties, bioactive peptides may be classified as antimicrobial, antihypertensive, opioid, antioxidative and etc. These peptides play a significant identity in human health. Progress of peptide and protein based therapeutic output for human use is growing continually as they carry on to receive an enhancing ratio of support by (US FDA). Peptide based drugs are a significant series of therapeutic agents but their progress into commercial products is often blocked due to their natural physico-chemical and biological instabilities. In this mini review, we characterize the recent methodologies and condition involved in the peptide and protein in industry in the therapeutic products section.

Keywords: Anti-oxidative peptides; Peptide in Industry; Bioactive peptides;Therapeutic

\section{Introduction}

Peptides can be planned to target a broad scale of molecules, giving them almost unqualified opportunities in fields such as oncology, immunology, infectious disease and endocrinology. For a summary of several general therapeutic peptides/ proteins. Presently emend the majority of the pharmaceutical market, peptides and proteins can be extremely selective as they have various points of contact with their goal [1]. Peptides hold great promise as new medicinal and biologic factors, and computational technique can assistance unlock that promise. In specific, structure-based peptide plan can be used to recognize and optimize peptide ligands [2]. Effective plan of high-attraction peptide ligands through rational techniques has been a major hindrance to the progress of this potential drug class. Although the protein and peptide remedial market has progressed necessary in the previous decades, delivery has confined their use [3]. The oral transfer of proteins and peptides is a dynamic investigation field despite the numerous contend narrow their impressive delivery. Effective oral delivery of proteins and peptides needs the achievement of three mainduties: conservation of the macromolecules from degradation in the gastrointestinal tract (GIT), penetration through the enteric block and attraction of molecules into the systemic rotation. Presently, no clinically valuable oral formulations have been progressed but several efforts have been prepared to overawe the challenges of down oral bioavailability resulting from low absorption and enzymatic degradation of the proteins and peptides in the GIT. Current plans effort to afford structural conservation of the proteins and peptides and enhanced attraction through the use of enzyme inhibitors, attraction enhancers, new polymeric delivery systems and chemical variation. Nevertheless, each of these technologies has their confines despite showing optimistic results [4].

\section{Anti-oxidative peptides}

The significance of oxidation in the body and in food materials has been extensively detected. Oxidative metabolism is necessary for permanence of cells. A side influence of this requirement is the manufacture of free radicals and other reactive oxygen classes that reason oxidative modifications. When an extra of free radicals is made, they can suppress preserver enzymes such as superoxide dismutase, peroxidase and catalase which cause harsh and lethal cellular factors (e.g. apoptosis) by oxidizing membrane lipids, DNA, and enzymes so shutting down cellular progression. Current studies have shown that anti-oxidative peptides can be dropped from caseins in hydrolysis by digestive enzymes and in fermentation of milk with proteolytic lactic acid bacteria strains [5].

\section{Bioactive peptide}

Bioactive peptides have concerned increasing attention as highlight candidates for different health-promoting useful foods. At current, milk proteins are the best identified source of such 
elements but until currently the commercial production of milk originated bioactive peptides has been confined by a lack of appropriate huge-measure technologies. Membrane separation methods appear to provide the best technology accessible for the enhancement of peptides witha particular molecular weight scale [6-8].

\section{Peptide in Industry}

Modern years have witnessed developing attention in the character of peptides. Enzymatic, chemical, or microbial hydrolysis of proteins in animal by-products or plant-source feed stuffs before feeding is an attractive means of generating highvalue minor or maximum peptides that have together nutritional and physiological or regulatory utilities. These peptides may also be shaped from processed proteins in the gastrointestinal tract, but the kinds of product peptides can differ almost with the physiological qualification of the animals and the mixture of the diets. Several peptides of animal or herbal originals also have antihypertensive, antioxidant and antimicrobial activities. Those peptides which consultation biological utilities beyond their nutritional significance are named bioactive peptides. Several minor peptides from animal yields (e.g., fish and meat) and herbal-source feedstuffs [9] have anti-oxidative utilities by inhibiting free radicals and/or scavenging the production of oxidants and pro-inflammatory cytokines [10-13]. These minor peptides can decrease the production of oxidants by the minor bowel, while improving the elimination of the oxidants, resultant in a decline in their intracellular concentrations and diminishing oxidative stress. $[14,15]$. In addition, several peptides from animal and herbal protein-hydrolysates [9] also have antimicrobial agents, as described for definite endogenous peptides in the minor intestine [16]. These antimicrobial peptides apply their actions by injuring the cell membrane of bacteria, meddling with the functions of their intracellular proteins, persuading the collection of cytoplasmic proteins, and affecting the metabolism of bacteria [17-19], but the fundamental mechanisms stay mostly unknown [16].

Now microbial medicine persistence has become a serious problem not only within inpatient setting but also within outpatient setting. Frequent intake and inessential usage of antibiotics as well as the transfer of resistance genes are the most significant elements that make the microorganisms resistant to common antibiotics. A huge number of antimicrobials effectively used for prophylaxis and therapeutic goals have now become ineffectual. Consequently, new molecules are being planned to be used in the treatment of several sicknesses. Various of these molecules are structural mixtures based on a mixture of peptides, for example, naturally happening endogenous peptide antibiotics and their synthetic analogues or molecules designed de novo expending (QSAR=quantitative structure activity relationships)-based methods. Trying to exploit numerous benefits of antimicrobial peptides like high potency and selectivity, wide kind of targets, potentially down toxicity and down reposition in tissues, pharmaceutical industry purposes to progress them as commercially available drugs and suitable clinical trials are being accomplished. In this paper we describe clinical trials phases and describe recent condition of several antimicrobial peptides below clinical development as well as briefly explain peptide drug formulation [20].

\section{Conclusion}

For developing factors Peptide therapeutics is a hopeful scope. Profits contain the facility and fast synthesis of peptides and volume for changes. An extensive and existent knowledge base of protein structure and function can be elicited for new peptide design. The subject falsehood in increasing the clinical usage of therapeutic peptides. Increasing delivery to tumors, minimizing non-particular toxic effects and understanding pharmacokinetic attributes are high between the requests to produce a potent therapeutic peptide for treatment. Knowledge according the connection among peptide function and structure also their mechanism of action is being practical in the design of antimicrobial peptide type of potential new therapeutic factors.

\section{Acknowledgement}

This study was supported by Tarbiat Modares University and Institute Pasteur.

\section{Conflict of interest}

The authors declare that there is no conflict of interest statement.

\section{References}

1. Craik DJ, Fairlie DP, Liras S, Price D (2013) The future of peptide-based drugs. Chem Biol Drug Des 81(1): 136-147.

2. Audie J, Swanson J (2013) Advances in the Prediction of ProteinPeptide Binding Affinities: Implications for Peptide-Based Drug Discovery. Chem Biol Drug Des 81(1): 50-60.

3. Vanhee P, van der Sloot AM, Verschueren E, Serrano L, Rousseau F, et al. (2011) Computational design of peptide ligands. Trends Biotechnol 29(5): 231-239.

4. Muheem A, Shakeel F, Jahangir MA, Anwar M, Mallick N, et al. (2016) A review on the strategies for oral delivery of proteins and peptides and their clinical perspectives. Saudi Pharmaceutical Journal 24(4): 413-428.

5. Korhonen H, Pihlanto A (2003) Food-derived bioactive peptidesopportunities for designing future foods. Curr Pharm Des 9(16): 12971308.

6. Kitts DD, Weiler K (2003) Bioactive proteins and peptides from food sources. Applications of bioprocesses used in isolation and recovery. Curr Pharm Des 9(16): 1309-1323.

7. Korhonen H (2002) Technology options for new nutritional concepts. International Journal of Dairy Technology 55(2): 79-88.

8. Emilie GP, Gauthier SF, Pouliot Y (2005) Membrane-based fractionation and purification strategies for bioactive peptides. In: Nutraceutical proteins and peptides in health and disease CRC Press, USA, pp. 639658.

9. López-BL, Gutiérrez-UJA, Serna-SSO (2014) Bioactive peptides and hydrolysates from pulses and their potential use as functional ingredients. J Food Sci 79(3): R273-R283.

10. Shimizu M, Ok SD (2007) Food-derived peptides and intestinal functions. Curr Pharm Des 13(9): 885-895. 
11. Bah CS, Bekhit AEDA, McConnell MA, Carne A (2016) Generation of bioactive peptide hydrolysates from cattle plasma using plant and fungal proteases. Food Chemistry 213: 98-107.

12. Memarpoor-YM, Asoodeh A, Chamani J (2012) A novel antioxidant and antimicrobial peptide from hen egg white lysozyme hydrolysates. Journal of Functional Foods 4(1): 278-286.

13. Power O, Jakeman P, Fitz GRJ (2013) Antioxidative peptides: enzymatic production, in vitro and in vivo antioxidant activity and potential applications of milk-derived antioxidative peptides. Amino Acids 44(3): 797-820.

14. Ryder K, Bekhit AED, Connell M, McCarne A (2016) Towards generation of bioactive peptides from meat industry waste proteins: Generation of peptides using commercial microbial proteases. Food chem 208: 4250 .

15. Zambrowicz A, Pokora M, Setner B, Dąbrowska A, Szołtysik M, et al. (2015) Multifunctional peptides derived from an egg yolk protein hydrolysate: isolation and characterization. Amino acids 47(2): 369380

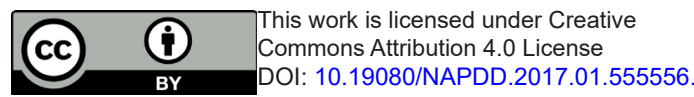

16. Bevins CL, Salzman NH (2011) Paneth cells, antimicrobial peptides and maintenance of intestinal homeostasis. Nat Rev Microbiol 9(5): 356-368.

17. Lima CA, Campos JF, Lima Filho JL, Converti A, Da Cunha MG, et al. (2015) Antimicrobial and radical scavenging properties of bovine collagen hydrolysates produced by Penicilliumaurantiogriseum URM 4622 collagenase. J food sci technol 52(7): 4459-4466.

18. Osman A, Goda HA, Abdel-HM, Badran SM, Otte J (2016) Antibacterial peptides generated by Alcalase hydrolysis of goat whey. LWT-Food Science and Technology 65: 480-486.

19. Wald M, Schwarz K, Rehbein H, Bußmann B, Beermann C (2016) Detection of antibacterial activity of an enzymatic hydrolysate generated by processing rainbow trout by-products with trout pepsin. Food chem 205: 221-228.

20. Greber KE, Dawgul M (2017) Antimicrobial Peptides under Clinical Trials. Curr top med chem 17(50): 620-628.

\section{Your next submission with Juniper Publishers will reach you the below assets}

- Quality Editorial service

- Swift Peer Review

- Reprints availability

- E-prints Service

- Manuscript Podcast for convenient understanding

- Global attainment for your research

- Manuscript accessibility in different formats ( Pdf, E-pub, Full Text, Audio)

- Unceasing customer service

Track the below URL for one-step submission https://juniperpublishers.com/online-submission.php 